\title{
PENGARUH DISIPLIN DAN KREATIVITAS BELAJAR TERHADAP HASIL BELAJAR MATEMATIKA DI SMK NEGERI DAN SWASTA
}

\author{
Ikmawati \\ Program Studi Pendidikan Matematika, Universitas Mulawarman \\ Email: ikmawati@fkip.unmul.ac.id
}

\begin{abstract}
ABSTRAK
Jenis penelitian ini adalah penelitian ex post facto. Populasi dari penelitian ini adalah siswa di kelas X SMK Negeri 5 Samarinda yang mewakili sekolah negeri dan kelas X SMK Farmasi Samarinda mewakili sekolah swasta. Sampel dalam penelitian ini adalah 35 siswa SMK negeri 5 dan 30 siswa SMK Farmasi Samarinda. Pengambilan data menggunakan instrument berupa tes soal essay untuk memperoleh data hasil belajar matematika dan angket untuk memperoleh data tentang disiplin belajar dan kreativitas belajar. Dari analisis inferensial menggunakan regresi linier ganda, diperoleh $F_{\text {hitung }}$ sekolah $(\mathrm{N})=5,31$ dan $F_{\text {tabel }} \operatorname{sekolah}(\mathrm{N})=3,27$ sedangkan $F_{\text {hitung }} \operatorname{sekolah}(\mathrm{S})=6,67$ dan $F_{\text {tabel }}$ sekolah $(\mathrm{S})=3,32$ karena $F_{\text {hitung }}$ sekolah $(\mathrm{N})$ dan sekolah $(\mathrm{S})>F_{\text {tabel. }}$. Hasil analisis $R^{2}$ sekolah $(\mathrm{N})=0,146$ menunjukkan kontribusi secara simultan sebesar $14,6 \%$ sedangkan $R^{2}(\mathrm{~S})=0,331$ menunjukkan kontribusi secara simultan sebesar $33,1 \%$, sehingga disimpulkan bahwa disiplin dan kreativitas belajar $(\mathrm{N})$ dan $(\mathrm{S})$ secara simultan berpengaruh terhadap hasil belajar matematika.
\end{abstract}

Kata kunci: Disiplin Belajar, Kreativitas Belajar, Hasil Belajar Matematika.

\begin{abstract}
This type of research is ex post facto research. The population of this study were students in class X of SMK Negeri 5 Samarinda representing public schools and class X of Samarinda Pharmacy Vocational School representing private schools. The sample in this study were 35 public vocational school students 5 and 30 students of Samarinda Pharmacy Vocational School, while the 36 tenth grade students of SMK IT Pratama as the sample test questions. Data retrieval uses an instrument in the form of essay test to obtain mathematics learning outcomes and questionnaires to obtain data about learning discipline and learning creativity. The results of inferential analysis using multiple linear regression, obtained $F_{\text {count }}$ by school $(\mathrm{N})=5.31$ and $F_{\text {table }}$ school $(\mathrm{N})=3.27$ while $F_{\text {count }}$ the school $(\mathrm{S})=6.67$ and $\mathrm{F}_{\text {table }}$ the school $(\mathrm{S})=3.32$ because $\mathrm{F}_{\text {count }}$ the school $(\mathrm{N})$ and school $(\mathrm{S})>\mathrm{F}_{\text {table }}$ are the expected regression models that are meaningful. $\mathrm{R}^{2}$ school analysis results $(N)=0.146$ shows simultaneous contribution of $14.6 \%$ while $R^{2}(S)=$ 0.331 shows simultaneous contribution of $33.1 \%$, so it is concluded that the discipline and creativity of learning $(\mathrm{N})$ and $(\mathrm{S})$ simultaneous effect on mathematics learning outcomes.
\end{abstract}

Keywords: Learning Discipline, Creativity Learning, Mathematics Learning Outcome. 


\section{PENDAHULUAN}

Keberhasilan belajar siswa dipengaruhi oleh faktor internal dan faktor eksternal. Faktor internal merupakan suatu hal yang mempengaruhi hasil belajar yang berasal dari dalam diri siswa itu sendiri diantaranya rasa percaya diri, kedisiplinan, kecerdasan, kreativitas, minat dan sebagainya. Sedangkan faktor eksternal merupakan suatu hal yang dapat mempengaruhi hasil belajar yang berasal dari luar diantaranya lingkungan keluarga, sekolah, masyarakat dan sebagainya.

Berdasarkan informasi yang peneliti dapatkan dari hasil observasi dan wawancara guru yang mengajar matematika di sekolah SMK Negeri 5 Samarinda (mewakili sekolah N) SMK Farmasi Samarinda (mewakili sekolah S) dan di sekolah, siswa menunjukkan kebisaan misalnya malas ke sekolah, datang selalu terlambat, mengganggu siswa lain yang sedang belajar, siswa mencontek pada waktu ulangan, pulang sebelum waktunya serta banyak perbuatan siswa yang merugikan dirinya. Untuk uji coba soal THB peneliti pilih di sekolah SMK TI Pratama Samarinda dan setelah dianalisis diperoleh soal yang layak diujikan.

Hasil wawancara dengan guru mata pelajaran matematika di kedua sekolah SMK Negeri 5 dan SMK Farmasi menunjukkan bahwa nilai ulangan semester pada mata pelajaran matematika masih tergolong rendah, karena masih banyak siswa yang nilainya belum sesuai dengan KKM, yaitu 75 .

\section{METODE PENELITIAN}

Penelitian ini bertujuan untuk mengetahui pengaruh disiplin dan krea- tivitas belajar terhadap hasil belajar matematika siswa pada materi barisan dan deret di Kelas X SMK Negeri dan Swasta Samarinda tahun pembelajaran 2018/2019. Berkaitan dengan paparan tersebut maka penelitian ini dilakukan oleh penulis dengan menggunakan rancangan penelitian ex post facto.

Ada tiga variabel yang digunakan, dua variabel bebas dan satu variabel terikat. Adapun variabel bebas dalam penelitian ini adalah kedisiplinan dilambangkan $\left(X_{1}\right)$ dan kreativitas dilambangkan $\left(X_{2}\right)$, sedangkan variabel terikatnya adalah hasil belajar matematika pada siswa yang dilambangkan dengan $(Y)$. Kemudian untuk melihat pengaruh antara variabel-variabel bebas dengan variabel terikat pada penelitian ini dibuatlah model rancangan penelitian.

Adapun model rancangan penelitian ini adalah sebagai berikut:

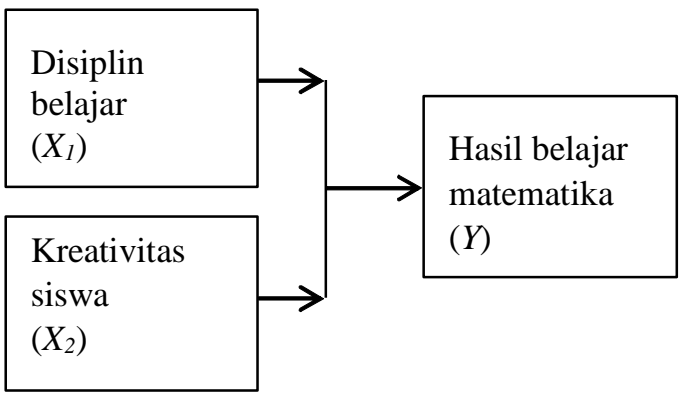

Gambar 1. Rancangan penelitian

\section{Teknik Pengumpulan Data}

\section{Tes Hasil Belajar Matematika}

Tes yang penulis gunakan dalam penelitian ini adalah tes tertulis. Tes ini dibuat oleh peneliti yang akan diberikan kepada responden penelitian berjumlah 5 soal dalam bentuk uraian. Nilai total yang diperoleh siswa apabila menjawab benar semua soal adalah 100. Sebelum tes digunakan untuk penelitian, maka perlu 
diujicobakan terlebih dahulu. Adapun kelas uji coba yaitu 30 siswa kelas $\mathrm{X}$ Multimedia di sekolah SMK TI Pratama Samarinda yang terdiri dari 10 soal. Uji coba dari tes hasil belajar dianalisis untuk mengetahui validitas, reabilitas, tingkat kesukaran serta daya pembeda.

\section{Angket}

Sugiyono (2013) menyatakan metode angket digunakan bila responden jumlahnya cukup besar, dapat membaca dengan baik dan dapat mengungkapkan hal-hal yang sifatnya rahasia.

Adapun langkah-langkah penyusunan angket sebagai berikut:

a. Mengadakan pembatasan materi yang akan diteskan.

b. Menentukan tipe soal berupa pernyataan.

c. Menyusun kisi-kisi angket penelitian.

d. Menguji coba angket dan menganalisa angket.

\section{HASIL PENELITIAN DAN PEMBA- HASAN}

\section{A. Hasil Penelitian}

1. Analisis Statistik Deskriptif
Berdasarkan Tabel 1, dapat diketahui skor disiplin belajar siswa lebih banyak pada kategori sangat tinggi baik di SMK Negeri 5 maupun di SMK Farmasi. Rata-rata skor SMK Negeri 5 adalah 67,17 sedangkan SMK Farmasi 66,8 ratarata kedua sekolah termasuk ke dalam kategori tinggi. Dari angket disiplin belajar siswa yang telah diisi oleh responden dapat diketahui bahwa pada saat ulangan matematika berlangsung, siswa cenderung mengerjakannya dengan tidak tenang dan terburu-buru. Hal tersebut terjadi karena siswa kurang yakin akan kemampuan yang dimilikinya. Terlihat dari kurangnya rasa optimis dalam menghadapi suatu persoalan, kurang yakin akan kemampuannya untuk mengatasi persoalan, dan kurangnya sikap displin untuk mengerjakan sesuatu sesuai dengan apa yang telah mereka rencanakan.

Berdasarkan Tabel 2, diketahu bahwa skor kreativitas siswa SMK Negeri 5 lebih banyak pada kategori sedang sedangkan SMK Farmasi lebih banyak pada kategori tinggi . Rata-rata skor SMK

Tabel 1. Distribusi frekuensi angket disiplin belajar siswa kelas X SMK Samarinda

\begin{tabular}{lccccc}
\hline \multicolumn{2}{c}{ Skor Disiplin Belajar Siswa } & \multicolumn{2}{c}{ SMK Negeri 5 } & \multicolumn{2}{c}{ SMK Farmasi } \\
\hline \multicolumn{1}{c}{ Interval } & Kategori & $\begin{array}{c}\text { Frekuensi } \\
\text { Persentase }\end{array}$ & $\begin{array}{c}\text { Frekuensi } \\
(\%)\end{array}$ & $\begin{array}{c}\text { Persentase } \\
(\mathrm{F})\end{array}$ & $(\%)$ \\
\hline $20 \leq x<30,81$ & Sangat Rendah & 0 & 0 & 0 & 0 \\
$30,81 \leq x<42,99$ & Rendah & 0 & 0 & 0 & 0 \\
$42,99 \leq x<55,16$ & Sedang & 1 & 2.9 & 0 & 0 \\
$55,16 \leq x<67,34$ & Tinggi & 14 & 40.1 & 12 & 39.9 \\
$67,34 \leq x \leq 80$ & Sangat Tinggi & 20 & 57.2 & 18 & 60 \\
\hline Skor Minmum & & \multicolumn{3}{c}{54} & \multicolumn{3}{c}{74} \\
\hline Skor Maksimum & & \multicolumn{3}{c}{75} \\
Rata-rata & \multicolumn{3}{c}{66,8} & \multicolumn{3}{c}{5,06} \\
Std. Deviasi & \multicolumn{3}{c}{4,91} \\
\hline
\end{tabular}


Negeri 5 adalah 51,94 termasuk ke dalam kategori rendah sedangkan SMK Farmasi rata-rata skornya adalah 56,27 termasuk ke dalam kategori sedang. Dari angket kreativitas belajar siswa yang telah diisi oleh responden dapat diketahui bahwa kreativitas belajar siswa sudah cukup baik. Hal tersebut dapat dilihat bahwa siswa rajin dalam mengerjakan soal yang diberikan oleh guru disekolah, dan juga rajin dalam mendiskusikan materi-materi pelajaran matematika baik sesudah ataupun sebelum materi tersebut diajarkan oleh bapak/ibu guru disekolah. Namun meskipun demikian, masih banyak siswa yang malas mengajukan diri untuk menjawab pertanyaan dari guru, siswa malas memikirkan dan mencoba sendiri cara baru yang lebih praktis untuk mengerjakan soal, dan juga masih banyak siswa yang malas mengerjakan PR yang telah diberikan oleh bapak/ ibu guru.

Berdasarkan Tabel 3 dapat dilihat bahwa siswa SMK Negeri 5 yang memperoleh nilai kurang dari 70 adalah sebanyak 42,9 persen dari seluruh sampel

Tabel 2. Distribusi frekuensi angket kreativitas belajar siswa kelas X SMK Samarinda

\begin{tabular}{|c|c|c|c|c|c|}
\hline \multicolumn{2}{|c|}{ Skor Disiplin Belajar Siswa } & \multicolumn{2}{|c|}{ SMK Negeri 5} & \multicolumn{2}{|c|}{ SMK Farmasi } \\
\hline Interval & Kategori & $\begin{array}{l}\text { Frekuensi } \\
\text { (F) }\end{array}$ & $\begin{array}{c}\text { Persentase } \\
\quad(\%)\end{array}$ & $\begin{array}{l}\text { Frekuensi } \\
\text { (F) }\end{array}$ & $\begin{array}{c}\text { Persentas } \\
(\%)\end{array}$ \\
\hline $20 \leq x<30,81$ & Sangat Rendah & 0 & 0 & 0 & 0 \\
\hline $30,81 \leq x<42,99$ & Rendah & 0 & 0 & 0 & 0 \\
\hline $42,99 \leq x<55,16$ & Sedang & 25 & 71.4 & 12 & 39.9 \\
\hline $55,16 \leq x<67,34$ & Tinggi & 10 & 28.6 & 16 & 53.3 \\
\hline $67,34 \leq x \leq 80$ & Sangat Tinggi & 0 & 0 & 2 & 6.7 \\
\hline Skor Minimum & & \multicolumn{2}{|c|}{44} & \multicolumn{2}{|c|}{43} \\
\hline Skor Maksimum & & \multicolumn{2}{|c|}{62} & \multicolumn{2}{|c|}{68} \\
\hline Rata-rata & & \multicolumn{2}{|c|}{51,94} & \multicolumn{2}{|c|}{56,27} \\
\hline Std. Deviasi & & \multicolumn{2}{|c|}{4,094} & \multicolumn{2}{|c|}{6,565} \\
\hline
\end{tabular}

Tabel 3. Distribusi frekuensi tes hasil belajar siswa kelas X SMK Samarinda

\begin{tabular}{lccccc}
\hline \multicolumn{2}{c}{ Skor Tes Hasil Belajar Siswa } & \multicolumn{2}{c}{ SMK Negeri 5 } & \multicolumn{2}{c}{ SMK Farmasi } \\
\hline \multicolumn{1}{c}{ Interval } & Kategori & $\begin{array}{c}\text { Frekuensi } \\
(\mathrm{F})\end{array}$ & $\begin{array}{c}\text { Persentase } \\
(\%)\end{array}$ & $\begin{array}{c}\text { Frekuensi } \\
(\mathrm{F})\end{array}$ & $\begin{array}{c}\text { Persenta: } \\
(\%)\end{array}$ \\
\hline $0 \leq x<52,11$ & Sangat Rendah & 1 & 2.9 & 4 & 13.3 \\
$52,11 \leq x<61,09$ & Rendah & 6 & 17.3 & 14 & 46.7 \\
$61,09 \leq x<70,07$ & Sedang & 8 & 22.9 & 4 & 13.3 \\
$70,07 \leq x<79,05$ & Tinggi & 13 & 37.3 & 3 & 10 \\
$79,05 \leq x \leq 100$ & Sangat Tinggi & 7 & 22.2 & 5 & 16.7 \\
\hline Skor Minimum & & \multicolumn{3}{c}{46} & \multicolumn{3}{c}{38} \\
\hline Skor Maksimum & & \multicolumn{3}{c}{93} & \multicolumn{3}{c}{62,67} \\
\hline Rata-rata & \multicolumn{3}{c}{70,17} & \multicolumn{3}{c}{11,55} \\
\hline Std. Deviasi & \multicolumn{3}{c}{10,04} \\
\hline
\end{tabular}


yang ada, dan hanya terdapat 59,5 persen siswa yang memperoleh nilai lebih dari 70. Sedangkan siswa SMK Farmasi yang memperoleh nilai kurang dari 70 adalah sebanyak 73,3 persen dari seluruh sampel yang ada, dan hanya terdapat 26,7 persen siswa yang memperoleh nilai lebih dari 70. Jadi dapat disimpulkan bahwa hasil belajar matematika pada materi barisan dan deret untuk SMK Negeri 5 Samarinda tergolong lebih baik dibandingkan SMK Farmasi Samarinda dilihat dari rata-rata SMK Negeri 5 masuk dalam kategori tinggi sedangkan SMK Farmasi rataratanya berada dalam kategori sedang.

\section{Analisis Statistik Inferensial}

Berdasarkan hasil analisis, diperoleh nilai probabilitas untuk SMK Negeri 5 adalah 0,026 dengan $t_{\text {hitung }}$ sebesar 2,334. Hal ini berarti $p=0,026<$ $\alpha=0,05$ maka $H_{0}$ ditolak dan didukung oleh $t_{\text {hitung }}=2,334>t_{\text {tabel }}=1,689$. Sedangkan SMK Farmasi probabilitasnya 0,003 dengan $t_{\text {hitung }}$ sebesar 2,796, hal ini berarti $p=0,003<\alpha=0,05$ maka $H_{0}$ ditolak dan didukung oleh $t_{\text {hitung }}=2,796>$ $t_{\text {tabel }}=1,697$. Ini menunjukkan bahwa dikedua sekolah baik di SMK Negeri 5 ataupun di SMK Farmasi mempunyai pengaruh yang signifikan antara kreativitas belajar dengan hasil belajar matematika siswa setelah memperhitungkan pengaruh variabel lain. Koefisien regresi untuk SMK Negeri 5 sebesar 0,935 sedangkan SMK Farmasi sebesar 0,846 artinya jika skor kreativitas belajar bertambah satu satuan maka nilai hasil belajar akan bertambah untuk SMK Negeri 5 sebesar 0,935 sedangkan SMK Farmasi bertambah sebesar 0,846 satuan dengan asumsi skor disiplin belajar tetap.

\section{B. Pembahasan}

1. Pengaruh secara simultan antara disiplin belajar dan kreativitas belajar terhadap hasil belajar matematika.

Matematika mempunyai peranan yang sangat penting dan memberikan manfaat yang besar pada kehidupan sehari-hari. Namun pada kenyataannya tidak sedikit siswa yang beranggapan bahwa matematika itu adalah pelajaran yang sulit dan sangat membosankan untuk dipelajari. Hal ini berdampak pada pencapaian hasil belajar matematika siswa yang kurang optimal.

Usaha dalam meningkatkan disiplin belajar dan kreativitas belajar diperlukan peranan orangtua dan guru ini merupakan hal yang sangat penting, jika orangtua sebagai orang terdekat siswa dirumah tidak memberikan perhatian yang cukup maka siswa sering telat dan malas untuk belajar, sehingga disiplin belajarnya semakin menurun.. Dalam meningkatkan disiplin belajar dan kreativitas belajar peranan guru sangatlah menentukan. Cara guru mengarahkan disiplin dan kreativitas belajar siswa tersebut dapat mempengaruhi hasil belajar matematikanya. Setiap siswa juga mempunyai kreativitas yang berbeda-beda.

Gambaran tentang pengaruh tersebut diperoleh dari koefisien determinasi $\left(R^{2}\right)$ di SMK Negeri sebesar 0,146 sedangkan di SMK Farmasi sebesar 0,331 hal ini berarti $14,6 \%$ di SMK Negeri 5 dan $33,1 \%$ di SMK Farmasi ini menunjukkan hasil belajar matematika siswa dapat dijelaskan oleh variabel disiplin dan kreativitas siswa. Sedangkan sisanya dijelaskan oleh faktor-faktor yang lain. Besaran kontribusi disiplin dan 
kreativitas siswa terhadap hasil belajar matematika dapat dikatakan cukup tinggi, akan tetapi faktor disiplin dan kreativitas siswa harus tetap diperhatikan dengan baik agar siswa dapat memperoleh hasil belajar matematika yang optimal tanpa mengabaikan faktor-faktor pendukung yang lain.

Dengan demikian, apabila guru, orang tua, dan pihak sekolah menginginkan hasil belajar yang memuaskan pada siswa, maka perlu adanya kerjasama atau kesesuaian sistem belajar antara orang tua selaku penanggung jawab anak di rumah dan guru sebagai penanggung jawab anak di sekolah untuk menciptakan suasana belajar yang benar-benar terfokus serta menunjang pelajaran anak, sehingga hasil belajar siswa khususnya mata pelajaran matematika akan meningkat dengan baik.

2. Pengaruh secara parsial antara disiplin belajar dan kreativitas belajar siswa terhadap hasil bela-jar matematika

Berdasarkan hasil analisis data, diperoleh persamaan regresi penduga di SMK Negeri 5 yaitu $\hat{Y}=19,844+0,026$ $X_{1}+0,935 X_{2}$ sedangkan di SMK Farmasi $\hat{Y}=11,913+0,402 X_{1}+0,846 X_{2}$. Model persamaan regresi tersebut dapat diartikan bahwa rata-rata nilai hasil belajar matematika diperkirakan akan meningkat sebesar 0,026 di SMK Negeri 5 sedangkan 0,402 di SMK Farmasi, untuk peningkatan skor angket disiplin belajar siswa sebesar satu satuan dengan asumsi bahwa variabel kreativitas belajar siswa konstan. Rata-rata nilai hasil belajar matematika siswa diperkirakan akan meningkat sebesar 0,935 di SMK Negeri 5 sedangkan di SMK Farmasi 0,846 untuk peningkatan skor angket kreativitas belajar siswa sebesar satu satuan dengan asumsi variabel disiplin belajar siswa konstan.

Hasil penelitian menunjukkan bahwa semakin tinggi disiplin belajar siswa maka semakin tinggi pula hasil belajar matematikanya. Pernyataan ini didukung dengan teori Syamsul (2013) bahwa disiplin adalah suatu kondisi yang tercipta melalui proses dan serangkaian perilaku yang menunjukkan nilai-nilai ketaatan, kepatuhan, keteraturan dan ketertiban.

Berdasarkan penjelasan teori di atas, bahwa siswa kurang bersikap disiplin sehingga mempengaruhi hasil belajar matematika yang rendah. Terlihat ketika siswa masih minum ketika guru sudah masuk kelas, tidak tepat waktu ketika mengerjakan tugas dan terlambat masuk kelas. Hasil belajar matematika yang dicapai juga masih dibawah KKM, sehingga dapat disimpulkan bahwa disiplin belajar berpengaruh positif terhadap hasil belajar matematika.

Hasil penelitian ini, juga menunjukkan bahwa semakin baik kreativitas belajar siswa maka hasil belajar matematikanya juga meningkat. Pernyataan ini didukung oleh teori Morena (dalam Slameto, 2010), yang penting dalam kreativitas itu bukanlah penemuan sesuatu yang belum diketahui orang sebelumnya melainkan bahwa produk kreativitas itu merupakan suatu yang baru bagi diri sendiri dan tidak harus merupakan sesuatu yang baru bagi orang lain. Hal ini mempunyai arti bahwa kreativitas belajar sebagai komponen penting dalam proses belajar mengajar matematika pada materi barisan dan deret 
yang mempengaruhi hasil belajar matematika siswa.

Berdasarkan analisis yang telah dilakukan, menunjukkan bahwa $\mathrm{H}_{0}$ baik di sekolah Negeri maupun di sekolah Swasta di tolak, maka terdapat pengaruh secara simultan atau secara parsial antara disiplin dan kreativitas belajar siswa terhadap hasil belajar matematika pada materi barisan dan deret di kelas X SMK Samarinda tahun ajaran 2018/2019. Ini menunjukkan tidak ada perbedaan berarti antara sekolah Negeri dan sekolah Swasta di Samarinda

\section{KESIMPULAN}

1. Terdapat pengaruh disiplin dan kreativitas belajar secara simultan terhadap hasil belajar matematika siswa pada materi barisan dan deret di kelas X SMK Samarinda Tahun Ajaran 2018/2019

2. Terdapat pengaruh yang signifikan secara bersama-sama dan secara parsial antara disiplin dan kreativitas belajar terhadap hasil belajar matematika pada materi barisan dan deret di kelas X SMK di Samarinda tahun ajaran 2018/2019.

3. Dari hasil analisis diketahui bahwa tidak ada perbedaan hasil belajar matematika yang dipengaruh disiplin dan kreativitas belajar siswa pada materi barisan dan deret tahun ajaran 2018/2019 SMK Negeri dan SMK Swasta di Samarinda.

\section{DAFTAR PUSTAKA}

Arikunto, S. (2012). Dasar-Dasar Evaluasi Pendidikan. Bumi Aksara.
Daryanto dan Suryatri. (2012). Implemen-tasi Pendidkan karakter di Sekolah. Gava Media.

Djemari, M. (2012). Pengukuran Penilaian dan Evaluasi Pendidikan. Nuha Litera.

Hamalik, O. (2010). Proses Belajar Mengajar. Raja Grafindo Persada.

Morrison, G R dkk. (2011). Designing Effective Instruction Sixth Edition. John Wiley and Son.

Purwanto. 2009. Evaluasi Hasil Belajar. Pustaka Pelajar.

Sasmito dkk. (2012). Model-Model Pembelajaran Inovatif. Unesa University Press Anggota Ikapi.

Slameto. (2010). Belajar dan Faktor yang Mempengaruhinya. Rineka Cipta.

Soedjadi, R. (2008). Kiat Pendidikan Matematika di Indonesia. Direktorat Jenderal Pendidikan Tinggi Depar-temen Pendidikan Nasional.

Sudijono, A. (2012). Pengantar Evaluasi Pendidikan. Rajagrafindo Persada.

Sudjana, N. (2012). Penilaian Hasil Proses belajar Mengajar. Remaja Rosdakarya.

Suherman, E. (2003). Strategi Pembelajaran Matematika Kontemporer. Universitas Pendidikan Indonesia.

Sugiyono. (2013). Metode Penelitian Pendidikan. Alfabeta.

Suprapto. (2013). Metodologi Penelitian Ilmu pendidikan dan Ilmu Pengetahuan Sosial. Buku Seru.

Syamsul, K. (2013). Pendidikan Karakter. ArRuzz Media.

Trianto. (2013). Mendesain Model Pembelajaran Inovatif-Progresif. Kencana Persada Media Group. 
| Jurnal PRIMATIKA, Volume 9, Nomor 1, Juni 2020

42 Pengaruh Disiplin dan Kreativitas Belajar Terhadap Hasil Belajar Matematika Ikmawati 